\title{
FORMULATION OF ORODISPERSIBLE TABLETS CONTAINING PARACETAMOL AND THEIR IN VITRO CHARACTERIZATION - A QbD APPROACH
}

\author{
ANDREI CĂTĂLIN MUNTEAN ${ }^{1 \#}$, OANA IULIANA NEGOI ${ }^{1 *}$, LUCA LIVIU RUS ${ }^{1}$, ANDREEA \\ LOREDANA VONICA $^{1 \#}$, IOAN TOMUŢA ${ }^{2}$ \\ 1 "Lucian Blaga” University of Sibiu, Faculty of Medicine, Romania \\ 2 "Iuliu Haţieganu” University of Medicine and Pharmacy, Faculty of Pharmacy, Cluj-Napoca, Romania \\ *corresponding author: negoi.oana@gmail.com \\ \#Authors with equal contribution.
}

Manuscript received: April 2019

\begin{abstract}
Quality by Design (QbD) concept in drug formulation and development was introduced in order to achieve and ensure a proper product quality through a good process understanding. By identifying the variability sources that influence the product characteristics, the product quality can be built from the development phase. By applying this concept, in the present experimental work was intended to develop and evaluate orodispersible tablets (ODTs) with paracetamol. In order to reach a good balance between their properties: quick disintegration, convenient hardness and a fast drug release, a statistical method was used. 36 formulations were prepared according to a D-optimal experimental design. The formulation factors used in the design were: the type of the diluent agent, the type of disintegrate agent, and the percentages of the disintegrant, sweetener and flavour. The obtained tablets were analysed in vitro for their friability, disintegration time, wetting time and dissolution profile. During this experiment it was observed that the mechanical properties were mainly influenced by the type of diluent agent used, the disintegrant agent and it's ratio in each formulation. The percentage of sweetener and flavour also influenced the dissolution profile, beside the other formulation variables. QbD approach was successfully applied within this study and the ODTs with paracetamol that have desired pharmaceutical characteristics may be successfully prepared.
\end{abstract}

\section{Rezumat}

Conceptul de calitate prin design $(\mathrm{QbD})$ a fost introdus în formularea şi dezvoltarea medicamentelor pentru a obţine şi a asigura o calitate adecvată produsului, având la bază o mai bună înţelegere a procesului. Calitatea produsului poate fi construită din faza de dezvoltare a acestuia, prin identificarea surselor de variabilitate care îi pot influenţa caracteristicile. Aplicând acest concept, în prezenta lucrare s-a urmărit obţinerea şi caracterizarea unor comprimate orodispersabile cu paracetamol, care să prezinte o dezagregare rapidă, o bună rezistenţă mecanică şi un profil de cedare in vitro optim. Pentru acest lucru s-au preparat 36 de tipuri de comprimate, conform unui plan experimental de optimizare. Variabilele de formulare au fost: tipul de diluant, tipul de dezagregant şi procentele de dezagregant, îndulcitor şi aromatizant. În vederea obţinerii unor variabile de răspuns, comprimatele au fost evaluate in vitro. Au fost evaluate friabilitatea, dezagregarea, rezistenţa mecanică, timpul de umectare şi profilul de dizolvare. Friabilitatea, dezagregarea şi rezistenţa mecanică au fost influenţate de tipul excipientului diluant folosit, de dezagregantul utilizat, dar şi de concentraţia acestuia. Profilul de dizolvare a fost influ enţat, pe lângă factorii amintiţi anterior şi de procentul de îndulcitor sintetic, dar şi de concentraţia aromatizantului. Conceptul de calitate prin design a fost aplicat cu succes acestui studiu, comprimatele orodispersabile obţinute având caracteristicile dorite.

Keywords: orodispersible tablets, paracetamol, quality by design, QbD, experimental design

\section{Introduction}

The oral route represents the most common route of drug administration; self-medication, accurate dosing, lack of pain, low cost and patient compliance are the main reasons for choosing this route, when possible $[13,17]$. Orodispersible tablets are easy to administer and suitable for children and people with dysphagia because do not require any additional water and have a rapid dispersion $[4,15]$. The drug bioavailability can be significantly higher than the one observed from the classical tablet dosage form [3, 5]. The Food and Drug Administration's (FDA) Guidance for Industry define, orally disintegrating tablets as solid dosage forms which disintegrate rapidly, in a matter of seconds, when placed upon a tongue. These tablets have to disintegrate very fast, in less than 3 minutes, according to the European Pharmacopoeia (Ph. Eur.) [9, 18, 19]. The ODTs have to have convenient organoleptic properties and an appropriate crushing strength in order to allow conventional packing $[5,18]$.

Quality by Design implies an in-depth knowledge and understanding the technological process for a specific pharmaceutical dosage form. It involves the analysis and control of all error sources, following the assumption 
that each step of the process is a possible source of variability $[6,12,14]$. Several regulatory documents offer guidance in understanding how QbD assists in ensuring the quality of a product and encourage the adoption of this concept by the pharmaceutical industry: International Conference on Harmonization (ICH) Q8 Pharmaceutical development, Q9 Quality risk management and Q10 Pharmaceutical quality system, Process Analytical Technology (PAT) and US FDA's Pharmaceutical cGMPs for $21^{\text {st }}$ century - a risk based approach $[7,11,14]$. By applying this concept, the relationships between the formulation, the process variables and desired quality features of the pharmaceutical product are well defined, allowing the establishment of design space which ensures that the required characteristics are fulfilled [7, 19].

The aim of this study was the development and optimization of orodispersible tablets with paracetamol by using the concept of quality by design in each formulation step. The experimental work was conducted by an experimental design in order to develop a formulation with appropriate mechanical properties, short disintegration time and fast dissolution. Our main objective was to obtain orodispersible tablets with paracetamol which have a good quality profile.

\section{Materials and Methods}

Apparatus. Analytical balance (Mettler Toledo MS, USA), tablet press (EK-0, Korsch, Germany), tablet hardness test apparatus (PharmaTest PTB-111, Germany), tablet disintegration test apparatus ZT 2 (Erweka, Germany), tablet friability test apparatus TA (Erweka, Germany), dissolution test apparatus (Pharmatest PTDT7, PharmaTest PTWS-100, Germany).

Materials. Paracetamol (Rhodapap 90\% DC - Novacyl, China) as active pharmaceutical ingredient. Mannitol (MAN, Roquette, France), isomalt 720 (ISO, Beneo Palatinit, Germany), Ludiflash ${ }^{\circledR}$ (LUD, BASF, Germany) used as diluent agents. Sodium croscarmellose (CCS, Ac-Di-Sol ${ }^{\circledR}$, FMC Biopolymer, Belgium) and crospovidone (CRP, Kollidon CL, BASF, Germany) as super-disintegrant agents. For better flowing properties of formulations, we used magnesium stearate (MS, Merck, Germany) and colloidal silicon dioxide (Aerosil, Evonik, Belgium). For the taste optimization we used sodium saccharine (SAC, Expertarom, Romania) and natural orange flavour (NOF, Expertarom, Romania).

Table I

QTPP of paracetamol orodispersible tablets

\begin{tabular}{|c|c|c|}
\hline Quality attribute & Target & Justification \\
\hline Dosage form & Tablets & \multirow{5}{*}{$\begin{array}{l}\text { Orodispersible tablets are suitable for } \\
\text { treatment of patients with dysphagia } \\
\text { and for special categories of patients } \\
\text { (children and elderly). }\end{array}$} \\
\hline Type of tablets & Orodispersible tablet & \\
\hline Administration route & Oral & \\
\hline Active substances & Paracetamol $250 \mathrm{mg}$ & \\
\hline Biopharmaceutical properties & $\begin{array}{l}\text { Immediate drugs release enabling } \\
\mathrm{T}_{\max } \text { in } 1.5 \text { hours or less }\end{array}$ & \\
\hline Indications & $\begin{array}{l}\text { Treatment of moderate to low } \\
\text { intensity pain } \\
\text { Treatment of fever associated with } \\
\text { cold and flu }\end{array}$ & $\begin{array}{l}\text { Because is one the most common OTC } \\
\text { used and recommended in all the } \\
\text { therapeutic guidelines for moderate to } \\
\text { low pain. }\end{array}$ \\
\hline Stability & $\begin{array}{c}\text { At least } 3 \text { years shelf life at room } \\
\text { temperature }\end{array}$ & Store at room temperature \\
\hline Container closure system & Blister PVC/Al, 10 tablets/blister & \\
\hline Tablet appearance & $\begin{array}{l}\text { White round tablets with smooth } \\
\text { surfaces and intact edges, with a } \\
\text { diameter of approx. } 12 \mathrm{~mm}\end{array}$ & \multirow{14}{*}{ Meeting the current USP requirements } \\
\hline \multicolumn{2}{|l|}{ Identification of active substances } & \\
\hline Paracetamol & positive & \\
\hline \multicolumn{2}{|l|}{ Assay of active substances } & \\
\hline Paracetamol & $250 \mathrm{mg} \pm 5 \%$ & \\
\hline \multicolumn{2}{|l|}{ Uniformity of content } & \\
\hline Paracetamol & $250 \mathrm{mg} \pm 15 \%$ & \\
\hline Disintegration & No more than 3 minutes & \\
\hline Crushing strength & $50-75 \mathrm{~N}$ & \\
\hline Dissolution & $\mathrm{Q}=75 \%$ at 45 minutes & \\
\hline \multicolumn{2}{|l|}{ Microbiological quality } & \\
\hline Total Aerobic Microbial Count (TAMC) & $<10^{3} \mathrm{CFU} / \mathrm{g}$ & \\
\hline Total combined Yeasts/Moulds (TYMC) & $<10^{2} \mathrm{CFU} / \mathrm{g}$ & \\
\hline Escherichia coli & Absence in $1 \mathrm{~g}$ & \\
\hline
\end{tabular}


FARMACIA, 2020, Vol. 68, 3

Quality by design ( $Q b D)$ approach for ODTs development. Identification of Quality Target Product Profile (QTPP), Critical Quality Attributes (CQAs) and assessment of risk factors. According to the ICH Q8 guideline, the QTPP contains the features that have direct correlation to the quality, safety, and efficacy attributes of the pharmaceutical product [7]. Table I presents the QTPP for the ODTs with paracetamol. The review of the literature, preliminary studies and quality attributes of the product represents the starting point for defining the CQAs of the product, in this case the disintegration time and dissolution profile. Ishikawa diagrams were used for risk assessment analysis and identification of the potential variables that might influence the quality attributes.

Risk assessment by Failure Mode Effects Analysis (FMEA). An overall risk evaluation is depicted in the Ishikawa diagrams (Figure 1) that contain all the process parameters that can influence or produce a failure concerning the quality of the final product. FMEA method allows the identification and prioritization of the failure modes that are most likely to cause product failure. The prioritization follows three criteria: frequency of occurrence, stringency of effects and difficulty of detection. Each of this attributes was evaluated on a scale from 1 to 5 , as follows: the occurrence $(\mathrm{O})$ was ranked as 5 for frequent, 4 for probable, 3 for occasional, 2 for remote and 1 for improbable; the severity (S), meaning the consequences of the failure mode, was classified as 5 for catastrophic, 4 for critical, 3 for serious, 2 for minor and 1 for negligible; finally, the third criterion, the detectability (D), meaning the difficulty to identify the failure mode, was ranked as 5 for hard to detect, 4 for low chance to be detected, 3 for moderately detectable, 2 for highly detectable, and 1 for easily detectable. The three attributes were evaluated for each of the considered critical process parameter (CPP). The failure risk was calculated as risk priority number $(\mathrm{RPN})=\mathrm{O} \times \mathrm{S} \times \mathrm{D}$ (Table II) [6]. The highest ranked CPPs were explored in the preliminary experiments and the further experimental design.

Table II

Failure mode effects analysis for risk assessment

\begin{tabular}{|c|c|c|c|c|c|c|c|c|}
\hline CPP/CMC & $\begin{array}{c}\text { Potential failure } \\
\text { mode }\end{array}$ & $\begin{array}{c}\text { Potential failure } \\
\text { effect }\end{array}$ & $\begin{array}{c}\text { Potential cause of } \\
\text { failure }\end{array}$ & Control methods & $O$ & $S$ & $D$ & $R P N$ \\
\hline Punch and die size & $\begin{array}{l}\text { Unsuitable punch } \\
\text { and die size }\end{array}$ & $\begin{array}{c}\text { Weight uniformity, } \\
\text { hardness, friability, } \\
\text { API release }\end{array}$ & $\begin{array}{l}\text { Unsuitable punch } \\
\text { and die size }\end{array}$ & $\begin{array}{c}\text { Measuring the } \\
\text { diameter and height }\end{array}$ & 1 & 5 & 2 & 10 \\
\hline Compression force & $\begin{array}{c}\text { Improper } \\
\text { compression force }\end{array}$ & $\begin{array}{c}\text { Hardness, friability, } \\
\text { API release }\end{array}$ & $\begin{array}{c}\text { Machine error, } \\
\text { human error, } \\
\text { different excipients }\end{array}$ & $\begin{array}{c}\text { Hardness test, } \\
\text { Disintegration test } \\
\text { Dissolution test }\end{array}$ & 2 & 5 & 3 & 30 \\
\hline $\begin{array}{c}\text { Qualitative } \\
\text { composition of the } \\
\text { formulation }\end{array}$ & $\begin{array}{c}\text { Unsuitable } \\
\text { concentration, } \\
\text { different type }\end{array}$ & $\begin{array}{c}\text { Hardness, friability, } \\
\text { API release }\end{array}$ & $\begin{array}{c}\text { Unsuitable } \\
\text { concentration, } \\
\text { different excipients }\end{array}$ & $\begin{array}{c}\text { Hardness test, } \\
\text { Friability test, } \\
\text { Disintegration test, } \\
\text { Dissolution test }\end{array}$ & 5 & 5 & 3 & 75 \\
\hline $\begin{array}{c}\text { Qualitative } \\
\text { composition of the } \\
\text { formulation }\end{array}$ & $\begin{array}{c}\text { Unsuitable } \\
\text { concentration, } \\
\text { different type }\end{array}$ & $\begin{array}{c}\text { Hardness, friability, } \\
\text { API release }\end{array}$ & $\begin{array}{c}\text { Unsuitable } \\
\text { concentration, } \\
\text { different excipients }\end{array}$ & $\begin{array}{l}\text { Hardness test, } \\
\text { Friability test, } \\
\text { Disintegration test } \\
\text { Dissolution test }\end{array}$ & 5 & 5 & 3 & 75 \\
\hline
\end{tabular}

$\mathrm{CPP}$ - critical process parameter; $\mathrm{CMC}$ - critical material characteristic; $\mathrm{O}$ - occurrence; $\mathrm{S}$ - severity; $\mathrm{D}$ - detectability; RPN - risk priority number

Design of experiments (DoE). This study was performed according to a D-Optimal experimental design. Modde 12.1 optimization software, Unmetrics, Sweden, was used for the experimental design construction, coefficients and statistical parameters computation and fitting of the experimental data in order to evaluate the results.

Table III

Experimental design variables

\begin{tabular}{|l|c|c|c|c|}
\hline \multicolumn{5}{|c|}{ Independent variables -formulation factors } \\
\hline \multirow{2}{*}{ Formulation factors } & \multirow{2}{*}{ Symbol } & \multicolumn{4}{c|}{ Level } \\
\cline { 3 - 5 } & & $-\mathbf{1}$ & $\mathbf{0}$ & $\mathbf{+ 1}$ \\
\hline Diluent agent type & $\mathrm{X}_{1}$ & $\mathrm{ISO}$ & $\mathrm{MAN}$ & LUD \\
\hline Disintegrant agent type & $\mathrm{X}_{2}$ & $\mathrm{CRP}$ & - & $\mathrm{CCS}$ \\
\hline Disintegrant \% & $\mathrm{X}_{3}$ & 4 & 9 & 14 \\
\hline Sweetener \% & $\mathrm{X}_{4}$ & 0 & 0,75 & 1,5 \\
\hline Flavour \% & $\mathrm{X}_{5}$ & 0 & 0,5 & 1 \\
\hline \multicolumn{2}{|c|}{ Dependent variables - responses } \\
\hline \multicolumn{2}{|c|}{ Symbol } & Is CQA? & Range for CQA \\
\hline Friability & $\mathrm{Y}_{1}$ & Yes & $0.00-1.00 \%$ \\
\hline Disintegration time & $\mathrm{Y}_{2}$ & Yes & $0-3 \mathrm{~min}$ \\
\hline Crushing strength & $\mathrm{Y}_{3}$ & Yes & $50-75 \mathrm{~N}$ \\
\hline
\end{tabular}


FARMACIA, 2020, Vol. 68, 3

\begin{tabular}{|l|c|c|c|}
\hline \multicolumn{1}{|c|}{ Responses } & Symbol & Is CQA? & Range for CQA \\
\hline Polydisperty index of crushing strength & $\mathrm{Y}_{4}$ & No & - \\
\hline Wetting time & $\mathrm{Y}_{5}$ & Yes & $0-3 \mathrm{~min}$ \\
\hline Polydisperty index of wetting time & $\mathrm{Y}_{6}$ & No & - \\
\hline \% of paracetamol released after 5 min. & $\mathrm{Y}_{7}$ & Yes & $<80 \%$ \\
\hline \% of paracetamol released after 10 min. & $\mathrm{Y}_{8}$ & Yes & $80-83 \%$ \\
\hline \% of paracetamol released after 15 min. & $\mathrm{Y}_{9}$ & Yes & $>83 \%$ \\
\hline Average dissolution time & $\mathrm{Y}_{10}$ & Yes & $0-3 \mathrm{~min}$ \\
\hline
\end{tabular}

Table IV

Experimental design matrix

\begin{tabular}{|c|c|c|c|c|c|c|c|c|c|c|c|c|c|c|c|c|}
\hline $\begin{array}{c}\text { Exp } \\
\text { Name }\end{array}$ & $\begin{array}{l}\text { Run } \\
\text { Order }\end{array}$ & $X 1$ & $X 2$ & $X 3$ & $X 4$ & $X 5$ & Y1 & $Y 2$ & $Y 3$ & $Y 4$ & $Y 5$ & Y6 & $Y 7$ & Y8 & Y9 & $Y 10$ \\
\hline N1 & 35 & ISO & CRP & 4 & 0 & 0 & 0.96 & 32.00 & 66.00 & 8.24 & 297.33 & 0.85 & 78.91 & 83.61 & 84.98 & 2.78 \\
\hline N2 & 20 & ISO & CRP & 14 & 1.5 & 0 & 0.49 & 28.00 & 65.00 & 6.80 & 130.67 & 4.61 & 76.87 & 82.03 & 82.24 & 2.82 \\
\hline N3 & 16 & ISO & CRP & 14 & 0 & 1 & 0.97 & 36.00 & 66.00 & 2.94 & 258.00 & 4.19 & 79.10 & 81.37 & 88.58 & 2.64 \\
\hline N4 & 32 & ISO & CRP & 4 & 1.5 & 1 & 0.88 & 31.00 & 66.00 & 7.32 & 384.00 & 0.52 & 80.11 & 85.42 & 86.63 & 2.81 \\
\hline N5 & 28 & ISO & CRP & 9 & 0.75 & 0.5 & 0.45 & 52.00 & 68.00 & 5.80 & 194.33 & 2.08 & 78.62 & 85.16 & 83.50 & 2.89 \\
\hline N6 & 7 & MAN & CRP & 4 & 0 & 0 & 10.79 & 19.00 & 63.00 & 7.33 & 30.00 & 6.67 & 83.77 & 85.15 & 85.72 & 2.54 \\
\hline N7 & 23 & MAN & CRP & 14 & 1.5 & 0 & 2.87 & 27.00 & 65.00 & 6.80 & 31.00 & 8.53 & 81.37 & 87.62 & 87.35 & 2.86 \\
\hline N8 & 17 & MAN & CRP & 4 & 0 & 1 & 5.30 & 20.00 & 63.00 & 13.28 & 25.33 & 6.03 & 87.11 & 93.78 & 84.76 & 2.86 \\
\hline N9 & 11 & MAN & CRP & 4 & 1.5 & 0.5 & 13.12 & 20.00 & 63.00 & 8.95 & 50.00 & 4.00 & 84.04 & 89.37 & 86.90 & 2.80 \\
\hline N10 & 5 & MAN & CRP & 14 & 0 & 0.5 & 3.95 & 24.00 & 65.00 & 2.51 & 41.67 & 3.67 & 78.62 & 83.97 & 87.03 & 2.82 \\
\hline N11 & 24 & MAN & CRP & 14 & 0.75 & 1 & 2.30 & 30.00 & 66.00 & 13.28 & 32.33 & 1.79 & 85.87 & 90.16 & 92.52 & 2.74 \\
\hline $\mathrm{N12}$ & 31 & MAN & CRP & 9 & 1.5 & 1 & 2.58 & 32.00 & 66.00 & 5.80 & 29.67 & 1.95 & 80.35 & 84.67 & 85.08 & 2.76 \\
\hline $\mathrm{N13}$ & 1 & LUD & CRP & 14 & 0 & 0 & 0.79 & 23.00 & 65.00 & 2.51 & 180.33 & 0.85 & 82.94 & 86.02 & 87.44 & 2.68 \\
\hline $\mathrm{N14}$ & 29 & LUD & CRP & 4 & 1.5 & 0 & 0.88 & 31.00 & 66.00 & 7.28 & 71.33 & 2.14 & 77.31 & 77.17 & 80.06 & 2.85 \\
\hline N15 & 34 & LUD & CRP & 4 & 0 & 1 & 0.84 & 27.00 & 65.00 & 6.92 & 35.67 & 4.28 & 76.48 & 86.67 & 89.36 & 3.09 \\
\hline N16 & 26 & LUD & CRP & 14 & 1.5 & 1 & 1.20 & 16.00 & 63.00 & 7.52 & 51.00 & 1.96 & 83.43 & 88.78 & 89.38 & 2.80 \\
\hline N17 & 12 & ISO & CCS & 14 & 0 & 0 & 0.61 & 108.00 & 69.00 & 4.61 & 484.00 & 0.21 & 68.30 & 80.73 & 83.26 & 3.27 \\
\hline $\mathrm{N18}$ & 18 & ISO & CCS & 4 & 1.5 & 0 & 0.39 & 116.00 & 71.00 & 3.76 & 542.00 & 0.55 & 62.00 & 92.95 & 96.40 & 4.17 \\
\hline N19 & 19 & ISO & $\mathrm{CCS}$ & 4 & 0 & 1 & 0.40 & 144.00 & 72.00 & 3.93 & 458.33 & 0.33 & 82.90 & 86.00 & 87.40 & 2.68 \\
\hline N20 & 13 & ISO & CCS & 14 & 1.5 & 1 & 0.19 & 152.00 & 73.00 & 5.29 & 482.00 & 0.41 & 65.45 & 86.48 & 89.52 & 3.72 \\
\hline N21 & 25 & MAN & CCS & 14 & 0 & 0 & 1.63 & 46.00 & 67.00 & 3.85 & 402.00 & 0.50 & 78.20 & 83.52 & 88.96 & 2.82 \\
\hline N22 & 33 & MAN & CCS & 4 & 1.5 & 1 & 1.90 & 49.00 & 67.00 & 5.31 & 87.00 & 1.15 & 78.80 & 85.76 & 84.95 & 2.91 \\
\hline N23 & 3 & MAN & CCS & 4 & 0 & 0.5 & 2.19 & 29.00 & 64.00 & 3.61 & 31.67 & 1.82 & 65.83 & 70.98 & 73.49 & 2.86 \\
\hline $\mathrm{N} 24$ & 21 & MAN & CCS & 4 & 0.75 & 0 & 4.67 & 28.00 & 65.00 & 6.80 & 110.00 & 1.82 & 77.72 & 81.91 & 83.79 & 2.76 \\
\hline N25 & 30 & MAN & CCS & 14 & 1.5 & 0.5 & 2.35 & 41.00 & 67.00 & 6.93 & 276.33 & 0.55 & 77.44 & 80.90 & 83.96 & 2.71 \\
\hline$N 26$ & 8 & MAN & CCS & 14 & 0.75 & 1 & 1.12 & 47.00 & 67.00 & 3.85 & 502.33 & 0.30 & 79.75 & 87.25 & 87.13 & 2.93 \\
\hline N27 & 10 & MAN & CCS & 9 & 0 & 1 & 1.04 & 30.00 & 66.00 & 4.52 & 185.00 & 1.08 & 77.75 & 81.22 & 84.30 & 2.71 \\
\hline N28 & 36 & MAN & CCS & 9 & 1.5 & 0 & 4.81 & 51.00 & 68.00 & 5.72 & 83.00 & 2.41 & 84.00 & 83.24 & 82.93 & 2.98 \\
\hline N29 & 9 & LUD & CCS & 4 & 0 & 0 & 0.75 & 32.00 & 66.00 & 4.72 & 72.33 & 2.11 & 84.83 & 90.80 & 91.83 & 2.83 \\
\hline N30 & 4 & LUD & CCS & 14 & 1.5 & 0 & 0.77 & 51.00 & 68.00 & 3.80 & 205.00 & 0.98 & 82.04 & 87.49 & 86.74 & 2.81 \\
\hline N31 & 22 & LUD & $\mathrm{CCS}$ & 14 & 0 & 1 & 0.85 & 48.00 & 67.00 & 3.15 & 228.67 & 0.67 & 81.74 & 90.31 & 88.88 & 2.98 \\
\hline N32 & 27 & LUD & CCS & 4 & 1.5 & 1 & 1.68 & 55.00 & 68.00 & 4.33 & 84.67 & 3.61 & 86.03 & 94.13 & 95.09 & 2.93 \\
\hline N33 & 2 & LUD & CCS & 9 & 0.75 & 0.5 & 0.62 & 34.00 & 66.00 & 2.94 & 131.33 & 0.88 & 80.18 & 86.61 & 81.93 & 2.87 \\
\hline N34 & 6 & LUD & CCS & 9 & 0.75 & 0.5 & 0.61 & 45.00 & 67.00 & 4.59 & 122.33 & 1.25 & 79.60 & 84.55 & 82.99 & 2.79 \\
\hline N35 & 15 & LUD & CCS & 9 & 0.75 & 0.5 & 0.84 & 41.00 & 67.00 & 4.22 & 125.33 & 7.37 & 83.43 & 85.31 & 87.29 & 2.61 \\
\hline N36 & 14 & LUD & $\mathrm{CCS}$ & 9 & 0.75 & 0.5 & 0.72 & 122.00 & 70.00 & 2.43 & 132.00 & 1.52 & 81.16 & 85.28 & 87.51 & 2.74 \\
\hline
\end{tabular}

$\mathbf{X}_{\mathbf{1}}$ - diluent agent type; $\mathbf{X}_{\mathbf{2}}$ - disintegrant agent type; $\mathbf{X}_{\mathbf{3}}$ - disintegrant $\% ; \mathbf{X}_{\mathbf{4}}$ - sweetener \%; $\mathbf{X}_{\mathbf{5}}-$ flavour $\% ; \mathbf{Y}_{\mathbf{1}}-$ friability; $\mathbf{Y}_{\mathbf{2}}-$ disintegration time; $\mathbf{Y}_{3}$ - crushing strength; $\mathbf{Y}_{\mathbf{4}}$ - polydisperty index of crushing strength; $\mathbf{Y}_{5}$ - wetting time; $\mathbf{Y}_{6}-$ polydisperty index of wetting time; $\mathbf{Y}_{7}-\%$ of paracetamol released in 5 minutes; $\mathbf{Y}_{\mathbf{8}}-\%$ of paracetamol released in 10 minutes; $\mathbf{Y}_{\mathbf{9}}-\%$ of paracetamol released in 15 minutes; $\mathbf{Y}_{\mathbf{1 0}}-$ average dissolution time.

Table III presents the variables used as formulation factors, and the dependent variables used for evaluating the product. The experimental design matrix is shown in Table IV.

Tablet preparation. Rhodapap granules together with compression excipients were mixed in a planetarymixer (PRS type, Erweka, Germany) for 10 minutes.
Tablets were obtained by direct compression, using an eccentric tablet press Korsch EK0, equipped with a $12 \mathrm{~mm}$ diameter set punch. The tablet press was adjusted so that the compressed tablets had an average weight of $750 \mathrm{mg}$, which is related to a concentration of $250 \mathrm{mg}$ of paracetamol/tablet. 
Determination of the dependent variables. The tablets were evaluated for their hardness, disintegration time and friability according to methods described in European Pharmacopoeia [19]. For the wetting time measurement, two pieces of round tissue paper were placed in a $10.0 \mathrm{~cm}$ diameter Petri dish, containing $10 \mathrm{~mL}$ of water with methylene blue. The tablet was placed on the tissue paper and the time until the medium from the dish reached the upper surface of the tablet was noted $[3,5]$.

The in vitro dissolution test was performed according to pharmacopoeia method, described in the USP and we used a type 2 apparatus, equipped with paddles, at a rotating speed of $75 \mathrm{rpm}[16,21]$. As dissolution media, $900 \mathrm{~mL}$ of phosphate buffer were used, with a $\mathrm{pH}$ of 5.8. $5 \mathrm{~mL}$ samples were taken at 5, 10, 15, 20, 25, 35 and 45 minutes and their paracetamol concentration was determined spectrophotometrically, at $243 \mathrm{~nm}$ using a validated method [16, 21].

\section{Results and Discussion}

The main objective of this experimental study was the development and optimization of ODTs with paracetamol. The QbD approach was used in each formulation step, with focus on the formulation parameters.

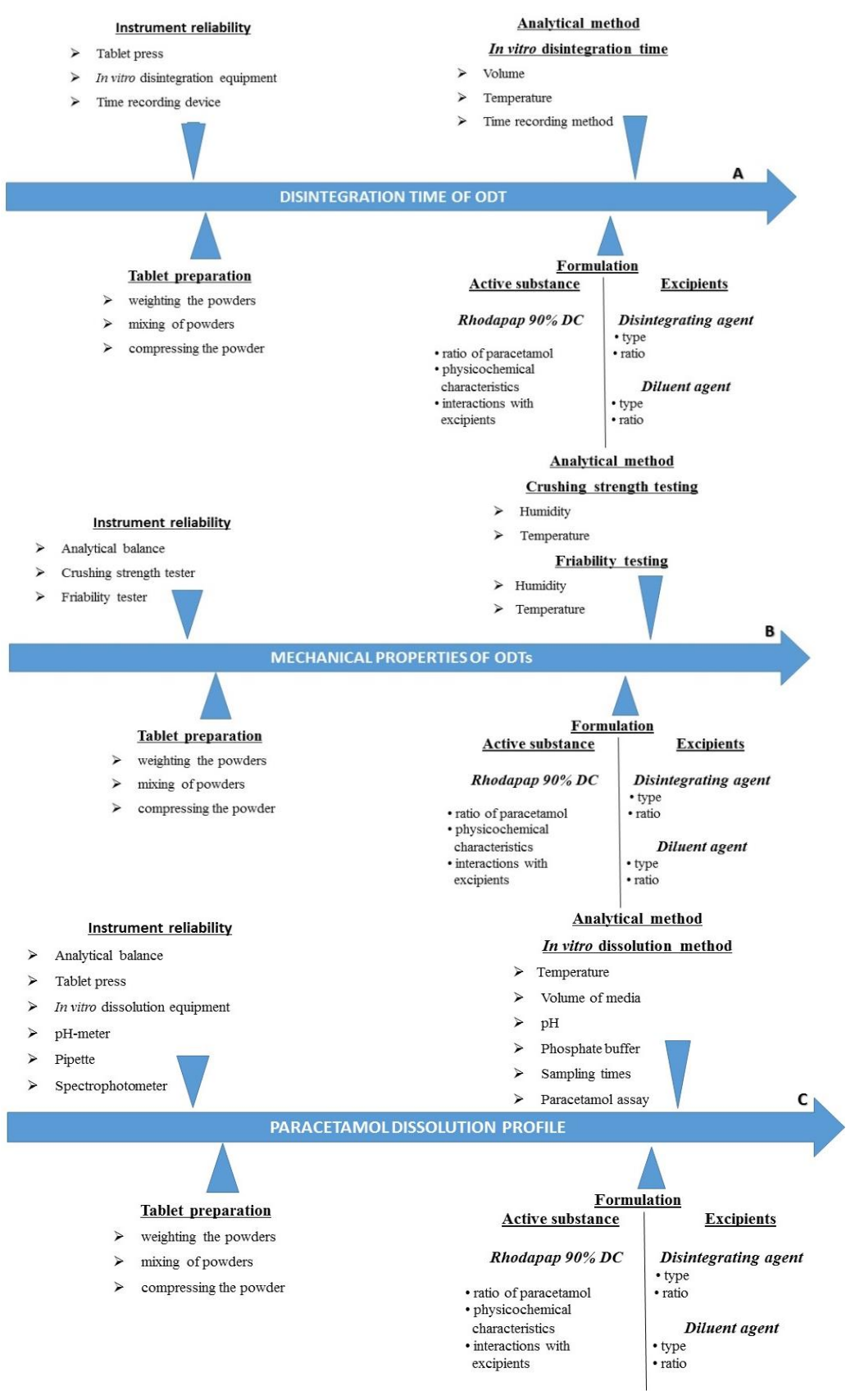

Figure 1.

Ishikawa diagrams for disintegration time (A); crushing strength (B) and dissolution profile (C) 
Risk assessment analysis. The QTPP was initially defined taking into consideration the dosage form and the preparation method, which was selected at the beginning of this study. The CQAs derived from this preliminary analysis were the disintegration time and the paracetamol dissolution profile of the ODTs. For the risk analyses were used Ishikawa diagrams (Figure 1), in which were considered the potential factors that might influence the attributes of the desired product. Factors related to formulation, technological process, instrument reliability and analytical method were evaluated. Instrument reliability and analytical method were not ranked with a high risk because the instruments are periodically calibrated and qualified and the analytical methods are validated.

The tablet preparation process consists in three main stages: weighting of raw materials, mixing the powder and compressing it. The weighting of raw materials and mixing process can be controlled by using equipment which are calibrated. The powder compression can be affected by using an unsuitable punch and die size, an improper compression force which can affect the mechanical properties of tablets which have a negative impact upon the disintegration time and the dissolution profile. This process can be controlled by measuring the diameter, the height and the hardness of tablets, in time. The formulation factors which influence the CQAs selected for this study are the type and the ratio of disintegrant agent and diluent used.
The risk consists in using an unsuitable concentration and another type of excipient.

Based on the risk evaluation, the formulation parameters in order to perform the study were the type of diluent agent $\left(\mathrm{X}_{1}\right)$, the type and ratio of disintegrant agent $\left(\mathrm{X}_{2}\right.$, $\mathrm{X}_{3}$ ). The sweetener and flavour were also included in the experimental design for the taste correction of tablets.

DoE analysis. For data analysis were considered the results presented in Table IV. Each formulation was evaluated and the results are listed for each response. Summary of fit. Modde 12.1 (Unmetrics, Sweden) was the optimization software used for experimental design and statistical analysis. The data fitting was done using the partial least squares method. The experimental design reliability was confirmed by the values of the following statistical parameters: $\mathrm{R}^{2}, \mathrm{Q}^{2}$, and ANOVA test. $\mathrm{R}^{2}$ indicates the variation fraction of the response explained by the model and $\mathrm{Q}^{2}$ the variation fraction of the response that can be predicted by the model; their values vary between 0 and 1 , but if they are closer to 1 , they show a very good model, with very good predictive power $[1,2,5,8]$. The results are presented in Table $\mathrm{V}$, where $\mathrm{R}^{2}, \mathrm{Q}^{2}$, model validity and reproducibility are represented for every response. The $\mathrm{R}^{2}$ value was between 0.6 and 0.91 for all the responses, except $Y_{8}$ and $Y_{9}$, for which the values are normal because 10 minutes after starting the dissolution test there is no more release of paracetamol from the tablets.

Table V

The fitting of the experimental data to the chosen model

\begin{tabular}{|c|c|c|c|c|c|}
\hline & $\mathbf{R}^{\mathbf{2}}$ & $\mathbf{Q}^{\mathbf{2}}$ & $\mathbf{R S D}$ & Model Validity & Reproducibility \\
\hline $\mathbf{Y}_{\mathbf{1}}$ & 0,820202 & 0,555519 & 0,206011 & 0,15652 & 0,974974 \\
\hline $\mathbf{Y}_{\mathbf{2}}$ & 0,926504 & 0,850444 & 9,88903 & 0,660334 & 0,97171 \\
\hline $\mathbf{Y}_{\mathbf{3}}$ & 0,780733 & 0,6334 & 1,25158 & 0,968352 & 0,45565 \\
\hline $\mathbf{Y}_{\mathbf{4}}$ & 0,715746 & 0,409783 & 1,39979 & 0,712599 & 0,792385 \\
\hline $\mathbf{Y}_{\mathbf{5}}$ & 0,880998 & 0,689224 & 0,168557 & 0,190033 & 0,982575 \\
\hline $\mathbf{Y}_{\mathbf{6}}$ & 0,728758 & 0,378948 & 1,29109 & 0,27338 & 0,974039 \\
\hline $\mathbf{Y}_{\mathbf{7}}$ & 0,69577 & 0,383188 & 3,57553 & 0,433996 & 0,899993 \\
\hline $\mathbf{Y}_{\mathbf{8}}$ & 0,57464 & $-0,09576$ & 3,25642 & 0,0162767 & 0,949912 \\
\hline $\mathbf{Y}_{\mathbf{9}}$ & 0,383967 & $-0,03017$ & 3,27349 & 0,810143 & 0,348742 \\
\hline $\mathbf{Y}_{\mathbf{1 0}}$ & 0,719687 & 0,498866 & 0,1828 & 0,59084 & 0,865714 \\
\hline
\end{tabular}

$\mathbf{R}^{2}$ - coefficient of determination; $\mathbf{Q}^{2}$ - predictive power of the model; RSD - relative standard deviation; $\mathbf{Y}_{\mathbf{1}}-$ friability; $\mathbf{Y}_{\mathbf{2}}$ - disintegration time; $\mathbf{Y}_{\mathbf{3}}$ - crushing strength; $\mathbf{Y}_{\mathbf{4}}$ - polydisperty index of crushing strength; $\mathbf{Y}_{5}$ - wetting time; $\mathbf{Y}_{\mathbf{6}}$ - polydisperty index of wetting time; $\mathbf{Y}_{\mathbf{7}}-\%$ of paracetamol released in 5 minutes; $\mathbf{Y}_{\mathbf{8}}-\%$ of paracetamol released in 10 minutes; $\mathbf{Y}_{\mathbf{9}}-\%$ of paracetamol released in 15 minutes; $\mathbf{Y}_{10}$ - average dissolution time.

Analysis of the influence of formulation factors on the mechanical properties of tablets. The effect of the factors variations and their interactions are shown in a number of histograms and response surfaces (Figures 2 and 3). The highest friability $\left(\mathrm{Y}_{1}\right)$ was obtained in the formulation which contains MAN, and better results were obtained for the formulations that had LUD in their composition, because of its quantitative composition. The type of disintegrant agent also influenced the friability results; the formulations with CCS had better results than the ones with CRP. 


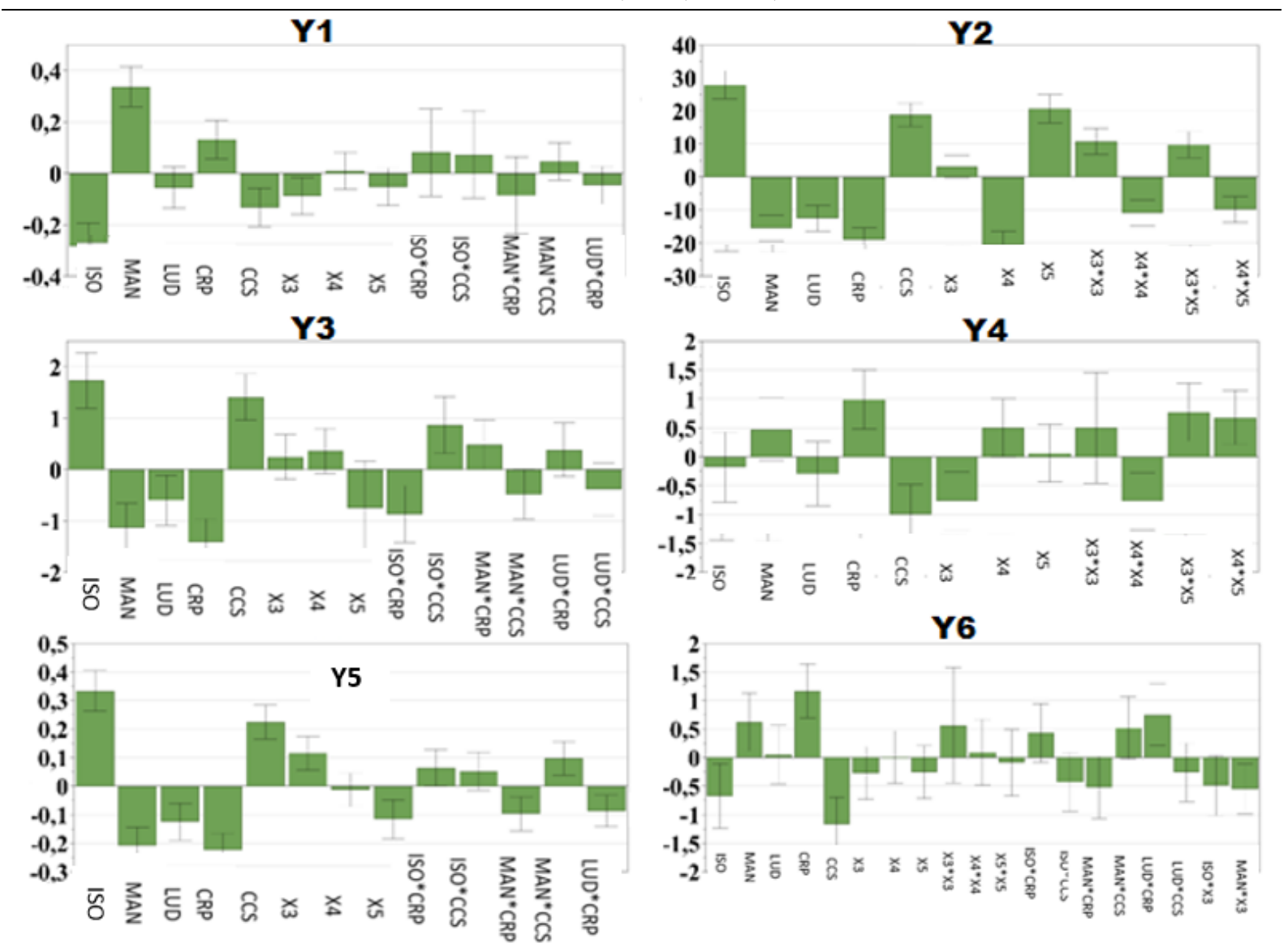

Figure 2.

Influence of formulation factors on the friability $\left(\mathrm{Y}_{1}\right)$, disintegration time $\left(\mathrm{Y}_{2}\right)$, crushing strength $\left(\mathrm{Y}_{3}\right)$, polydisperty index of crushing strength $\left(\mathrm{Y}_{4}\right)$, wetting time $\left(\mathrm{Y}_{5}\right)$, polydisperty index of wetting time $\left(\mathrm{Y}_{6}\right)$
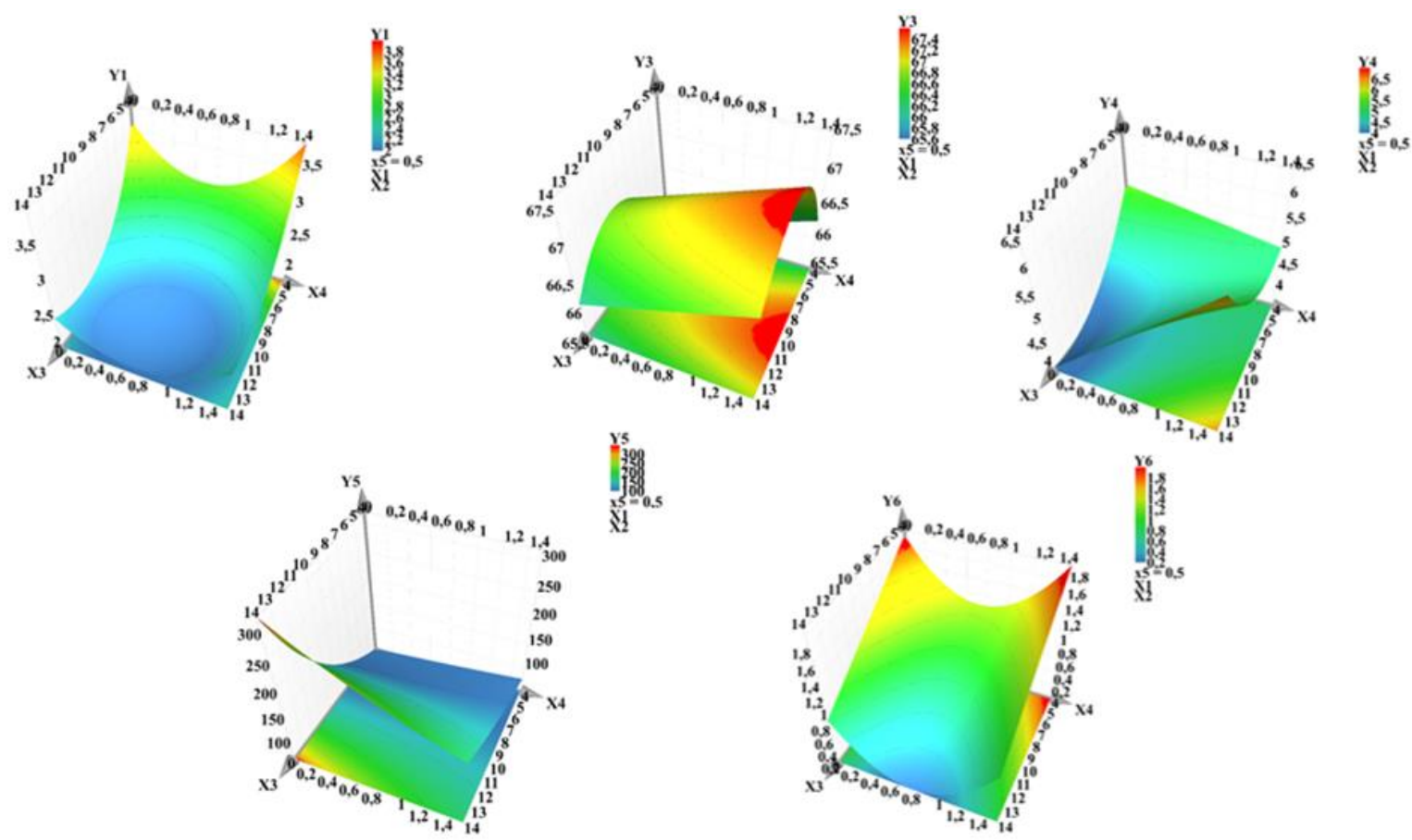

Figure 3.

Influence of the formulation factors on the friability $\left(\mathrm{Y}_{1}\right)$, crushing strength $\left(\mathrm{Y}_{3}\right)$, polydisperty index of crushing strength $\left(\mathrm{Y}_{4}\right)$, wetting time $\left(\mathrm{Y}_{5}\right)$, polydisperty index of wetting time $\left(\mathrm{Y}_{6}\right)$ 
The disintegrating time $\left(\mathrm{Y}_{2}\right)$ was influenced by the type of diluent, higher values were obtained for the formulations with ISO; the best values were for the formulations with LUD and MAN. For the formulations with CRP the results determined experimentally were better than the ones for the tablets with CCS.

A significant interaction was observed between ISO and CCS, which determines a higher disintegration time for those formulations. For all formulations were recorded low disintegration times, less than 3 minutes (180 seconds), as mentioned in the $\mathrm{Ph}$. Eur.

Tablets that contained ISO, as well as the ones with CRP, had a higher crushing strength $\left(\mathrm{Y}_{3}\right)$. The presence of ISO in the formulation influenced the crushing strength, but the best values were obtained for the formulations that had CRP and ISO in the formulation.

The wetting time $\left(\mathrm{Y}_{5}\right)$ results were in correlation with the disintegration time results. The presence of ISO in the formulation increased the wetting time. The same happened for the tablets with CRP. Good results were obtained for the formulations with LUD and CCS.
The results obtained after the mechanical properties evaluation can be explained because of the tablet composition. Mannitol is a good diluent agent used for this kind of dosage forms preparations, for its properties. The friability and disintegration of the tablets with MAN are influenced by their particle size; this may be corrected by performing a granulation first [10]. The mechanical properties of formulations with LUD were better because of their content in CRP, which confers extra properties to tablets and the results obtained improved [20]. The formulations that had ISO in their compositions, had better mechanical properties because ISO 720 was used, which is suitable for direct compression. Both, CCS and CRP, used as disintegrant agents, can be used for direct compression; the difference between their structures influences their capacity of absorbing water and the disintegration time [10].

Analysis of the influence of the formulation factors on the dissolution profile of paracetamol. The dissolution profiles of the 36 types of tablets are presented in Figure 4 and the effect of the factors and their interactions are presented in Figure 5.

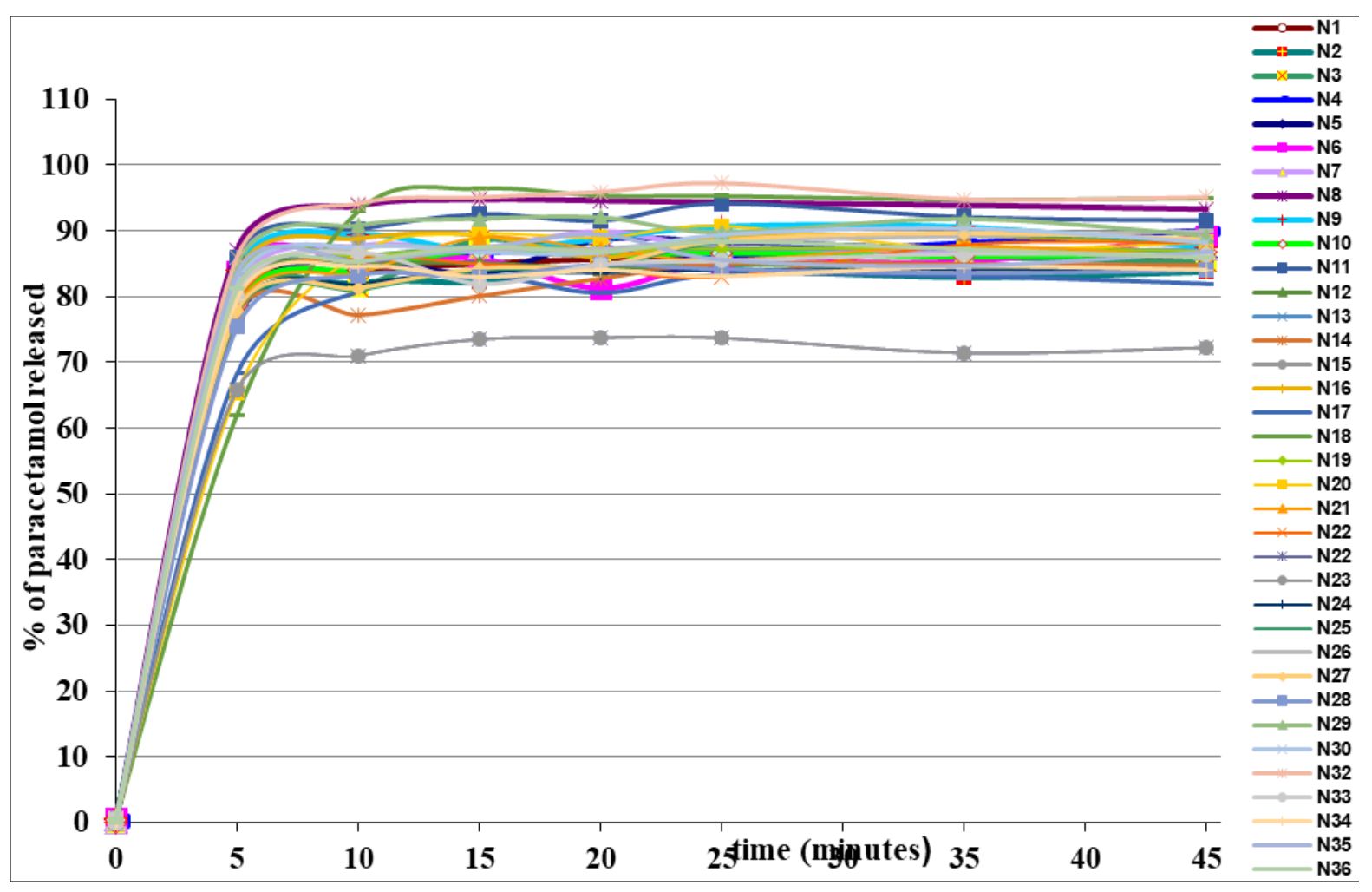

Figure 4.

Dissolution profiles for the 36 formulations

N1 - N36 - Formulas resulted from DoE 

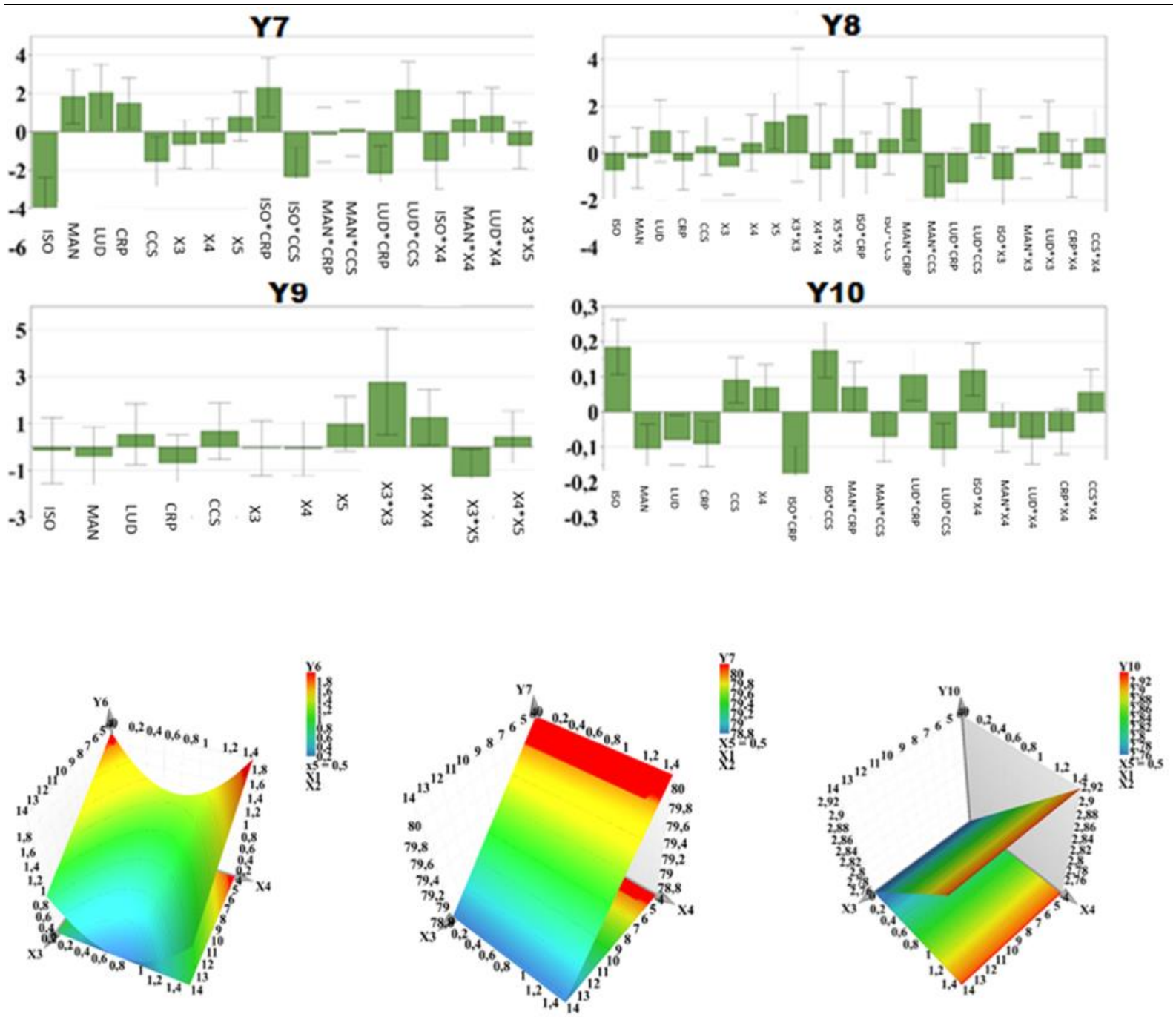

Figure 5.

The influence of the formulation factors on the dissolution profiles of paracetamol $\mathrm{Y}_{7}-\%$ of paracetamol released in 5 minutes; $\mathrm{Y}_{8}-\%$ of paracetamol released in 10 minutes; $\mathrm{Y}_{9}-\%$ of paracetamol released in 15 minutes; $\mathrm{Y}_{10}$ - average dissolution time

32 of the formulations released more than $75 \%$ of the total amount of API in 5 minutes. The percentage was higher for the formulations with MAN, LUD and CRP. Better results were obtained for the tablets with LUD and CCS. After 10 and 15 minutes the percentage of paracetamol released was almost the same, because, as shown in Figure 6, the quantity of released API stayed at the same level. All the formulations, except N23, were in accordance with the USP specifications and the quantity released after 45 minutes was greater than $75 \%$.

The average dissolution time was influenced by the content of synthetic sweetener. For the tablets that contained a combination of SAC and CCS, the results obtained were higher than the ones with SAC and CRP.

Design space and optimal formula determination. The optimal formulation was determined with Modde 12.1 software, in which the best conditions for obtaining a good crushing strength, the shortest disintegration time and the best dissolution results were generated. As a result, for good mechanical properties and dissolution profile isomalt is preferred as diluent, sodium croscarmellose as disintegrant, $4 \%$, and $1 \%$ of natural orange flavour. 

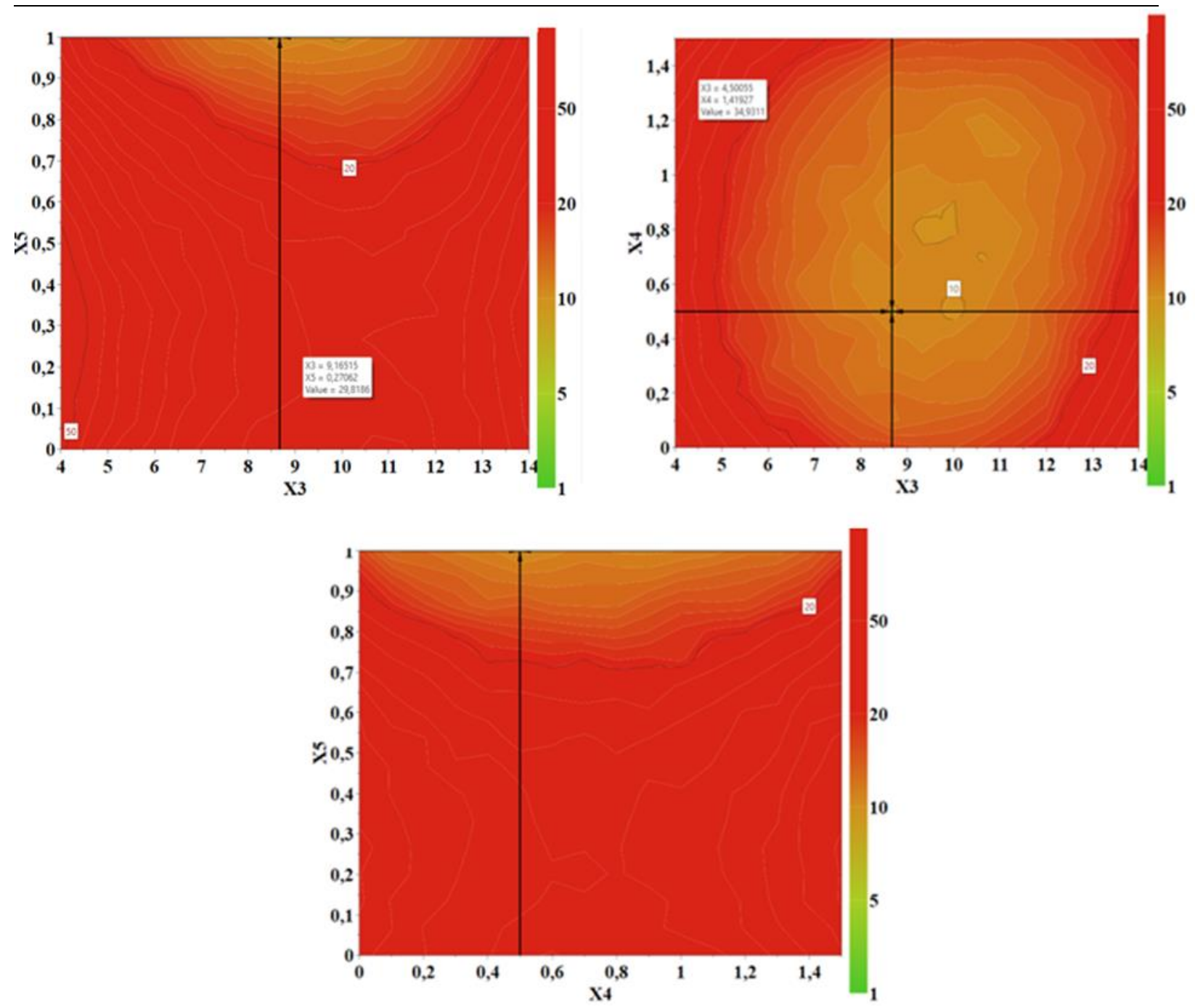

Figure 6.

Design space of optimal formulation $\left(\mathrm{X}_{3}\right.$ - disintegrant $\%, \mathrm{X}_{4}-$ sweetener $\%, \mathrm{X}_{5}-$ flavour \%)

\section{Conclusions}

The current worked aimed to develop orodispersible tablets with paracetamol, and studying the influence of formulation factors on the results obtained in their pharmaceutical characterization. By applying the QbD concept, the desired quality product quality profile (QTPP) and critical product quality (CQA) were defined. Thirty-six experimental formulations were prepared and evaluated in order to identify formulation factors issues that may influence the quality characteristics of ODTs. The results revealed that isomalt 720 was the best diluent agent, which makes it suitable for this kind of dosage forms. A high percentage of disintegrant had no influence on the dependent variables analysed, as shown by the fact that good responses were obtained at a low disintegrant content. The results showed that using sodium croscarmellose led to better results than using crospovidone. The presence of sweetener had a bad influence upon the answers, which was proven by the fact that the optimal formulation obtained did not include any sweetener. The natural orange flavour had a good influence; the formulations that contained this agent had good results in all determinations.

\section{Conflict of interest}

The authors declare no conflict of interest.

\section{References}

1. Alecu C, Tomuță I, Dudaș D, Leucuța S, Mircioiu C, Optimization of metoprolol tartrate modified release matrix tablets formulation using Surelease as binder for granulation. Farmacia, 2013; 61(6): 1117-1130.

2. Eriksson L, Johansson E, Kettaneh-Wold N, Wikstrom C, Wold S, Design of Experiments: Principles and Applications. $3^{\text {rd }}$ Edition. Umetrics Academy, Umea, 2008.

3. Gautam SP, Rai JP, Billshaiya U, Jain N, Vikram $\mathrm{P}$, Jain DK, Formulation and evaluation of Mouth Dissolving Tablet of Loperamide. Int J Pharm Sci Res., 2013; 4(5): 1782-1788.

4. Husseiny RA, Abu Lila AS, Abdallah MH, Elghamry HA, Fast disintegrating tablet of Valsartan for the treatment of pediatric hypertension: in vitro 
and in vivo evaluation. J Drug Deliv Sci Tech., 2018; 43: 194-200.

5. Iurian S, Tomuţă I, Leucuţa SE, Formulation of orodispersible tablets containing meloxicam and their in vitro and in vivo characterization. Farmacia, 2014; 62(6): 1097-1108.

6. Iurian S, Turdean L, Tomuţă I, Risk assessment and experimental design in the development of a prolonged release drug delivery system with paliperidone. Drug Des Devel Ther., 2017; 11: 733-746.

7. ICH Harmonized Tripartite Guideline: Pharmaceutical Development, Q8 (R2). www.ich.org/fileadmin/Public_ Web_Site/ICH_Products/Guidelines/Quality/Q8_R 1/Step4/Q8_R2_Guideline.pdf

8. Leucuța S, Tomuță I, Design of Experiments and Drugs Formulation and Optimization, Ed. Risoprint, Cluj-Napoca, 2011.

9. Popovici I, Lupuleasa D, Pharmaceutical Technology, Vol. III, $2^{\text {nd }}$ edition, Ed. Polirom, Iaşi, 2017; 551, (available in Romanian).

10. Rowe RC, Sheskey PJ, Quinn ME, Handbook of Pharmaceutical Excipients $6^{\text {th }}$ edition, RPS Publishing, 2009; 206-210.

11. Sangshetti JN, Deshpande M, Zaheer Z, Shinde DB, Arote R, Quality by design approach: Regulatory need, Arab J Chem., 2017; 10: S3412-S3425.

12. Schlihdwein WS, Gibson M, Pharmaceutical Quality by Design: a practical approach, Wiley \& Sons Ltd., 2018; 61-91, 157-198.
13. Suciu Ş, Iurian S, Bogdan C, Iovanov R, Rus L, Moldovan M, Tomuță I, QbD approach in the development of oral lyophilisates with ibuprofen for pediatric use. Farmacia, 2018; 66(3): 514-523.

14. Tefas LR, Rus LM, Achim M, Vlase L, Tomuţă I, Application of the quality by design concept in the development of Quercetin-loaded polymeric nanoparticles. Farmacia, 2018; 66(5): 798-810.

15. Terán Martinez ME, Flament MP, Development of multiparticulate orodispersible tablets for pediatric use. Int J Pharmaceut., 2016; 511: 1127-1150.

16. Tomuţă I, In vitro release of active drug substance from pharmaceutical products, Ed. Risoprint, ClujNapoca, 2014; 64-67, 156, (available in Romanian).

17. Vivek D, Renu BY, Richa A, Sachdev Y, Formulation design and optimization of novel fast dissolving tablet of chlorpheniramine maleate by using using lyophylization techniques. Bull Faculty Pharm Cairo Univ., 2017; 55: 31-39.

18. ***Food and Drug Administration. Guidance for industry orally disintegrating tablets 2008. U.S. Department of Health and Human Services Food and Drug Administration Center for Drug Evaluation and Research (CDER).

19. ***European Pharmacopoeia 9.0. Edition 2016; 299-313.

20. ***Material Safety Data Sheet - Ludiflash, BASF, Germany.

21. ***USP.30.NF25 - Acetaminophen tablets. 